\title{
Challenges of Teaching and Learning Business Education with New Technologies in Rivers State Universities
}

\author{
Ukata, Philip Festus \\ Department of Office Technology and Management, School of Business and Administrative Studies, Captain Elechi Polytechnic, Rumuola, Port- \\ Harcourt, Nigeria \\ Email: ukata4mephilip@yahoo.com \\ Silas-Dikibo, I. Deborah \\ Department of Office Technology and Management, School of Business and Administrative Studies, Port-Harcourt Polytechnic, Rumuola, Port- \\ Harcourt, Nigeria
}

Received: 19 August 2019; Revised: 23 September 2019; Accepted: 2 October 2019; Published: 17 October 2019

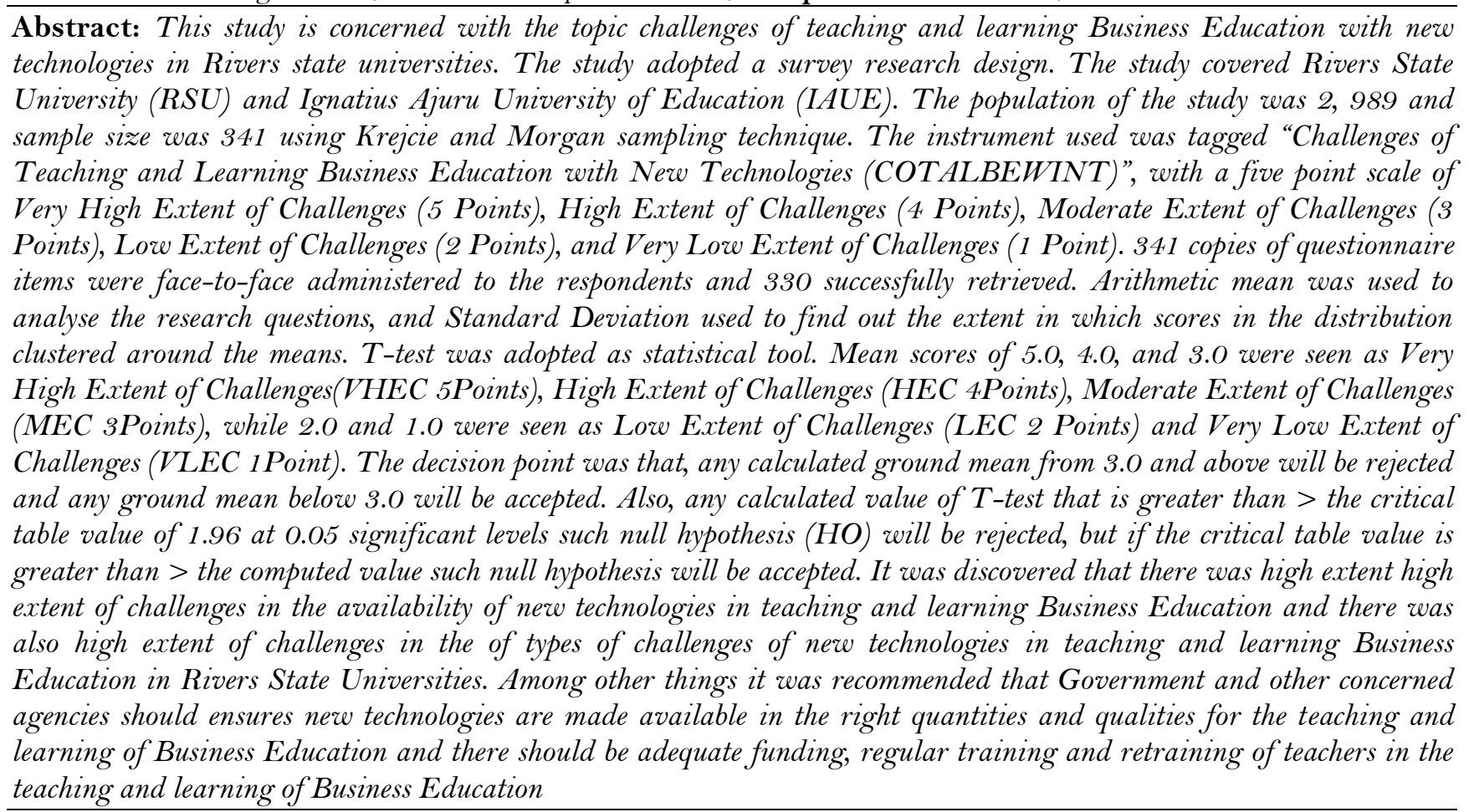
Keywords: Challenges, Teaching, Learning, Business education, New technologies

\section{Introduction}

Teaching is an attempt to assist people to acquire some skills, attitudes, knowledge or ideas. Teaching is also an interaction between teachers and students under the auspices and responsibilities of the teacher in order to bring about the expected change in the students' behavior. Teaching profession is an act of relating information to the learner or assisting in the learner of how to do something (Awotua-Efebo, 1999). It involves the process of assisting the learner to gain useful skills, attitudes, knowledge, ideas; values in an arranged or unarranged environment that will assist the learner become an acceptable person to the society as well as be independent in life. Teaching is an exchange of ideas between a teacher and a student(s) on how to learn through the use of instructional methods and technologies. Teaching is an interaction between teachers and students, students and students, students and environment under the auspices and responsibilities of the 
teacher in order to bring about the expected change in the students behavior through the use of instructional methods and technologies (Ukata, 2017). Teaching leads to learning, learning leads to experience and experience to attitude and behaviour.

Theelearningcoach.com (2018) posited that learning is the relatively permanent change in a person's knowledge or behaviour due to experience. This definition has three components: 1) the duration of the change is long-term rather than short-term; 2) the locus of the change is the content and structure of knowledge in memory or the behaviour of the learner; 3) the cause of the change is the learner's experience in the environment rather than fatigue, motivation, drugs, physical condition or physiologic intervention." Teaching and learning of Business Education as employable course depends on the use of instructional methods, environment and technologies which may be old or new technologies. Ugwuogo, (2013) argued that Business Education is a form of vocational education that is directed towards developing the learner to become productive in teaching, paid employment and self-employment. Business Education prepares beneficiaries for gainful employment and sustainable livelihood. It is generally seen as education for and about business. Business Education for business is that aspect of vocational education which provides instruction and preparation for office occupations such as secretary, shorthand-typist or stenographer, bookkeeper, data processor, word processor, computer analyst and accountant.

On the other hand, education about business provides knowledge and understanding of the economic, financial, marketing, accounting, management system and other branches of business endeavour. In other words, education about business prepares students to function intelligently as consumers and citizens in a business economy. Amoor (2010) noted that Business Education plays significant role in the economic development by providing knowledge and skills to the learners, thereby, enabling them to adequately impart knowledge to others, and handle sophisticated office technologies and information systems. The goal of Business Education is primarily to produce competent, skilful and dynamic business teachers, office administrators and businessmen and women that will effectively compete in the world of work. It has as its primary aim for the preparation of people for roles in enterprises such employee, entrepreneur and employer or simply as self-employed in which it content delivery may be impossible without new technologies.

However, over the centuries even with evolution of classroom technologies and management, teachers and students alike have depended on orthodox instructional technologies and techniques such as Beads, Wooden Roller, Counting sticks, striking on the wall with Charcoal and Cane for demonstration etc., and instructional techniques like "talk and write" "listen and take note" "dictate and explain" etc., in teaching course that give entrepreneurial skills which seems grossly inadequate and ineffective. Onyesom and Utoware (2012) posited that; the emergence of new technologies in teaching and learning has revolutionized the entire education system. Onyesom (2014) observed that, great deals of instructional and administrative functions in Business Education are still carried out manually and traditionally. Onyesom further stressed that, lecturers in Business Education programs still depend on the traditional method of "chalk and talk" approach.

This reflects the fact that most Nigerian students for Business Education have acquired overdose of theoretical knowledge which does not seem to match today's demand of global workplaces practical entrepreneurial skills. Ekundayo (2009) also lent his voice that teaching and learning has gone beyond the teacher standing in front of the students and disseminating information to them without students' preparation and participation. Onyesom (2014) maintained that, education penetrating influence of new technologies has impacted on the quality and quantity of teaching, learning and research in conventional and distance education system as a result of its quantum benefits. Business Education program content is an inclusive beneficiary of the said quantum of benefits. The question is, are these benefits free of challenges?. Haagi, Cummings and McCubery (2002), saw new technologies as emerging in most business and have not been exploited, or it is fairly established but businesses have not exploited it. The reasons for not exploitation may not be unconnected with the degree of challenges. Osuala (2004), viewed new technologies as emerging and developing forces. There is absolutely no controversy about the above statement and the fact that software and hardware devices have not only revolutionized education and communication sector but have also brought positive and remarkable changes and achievements in the ways and manner people co-exist and do things in the society.

\subsection{Concept of Nerw Technologies}

The term "new technology or technologies" according Jegbefume, Utebor and Kifordu (2014), originated from earlier terms such as information technology (IT) and information and communication technology (ICT), which deal with accessing, gathering, manipulating and making available or communicating information. The

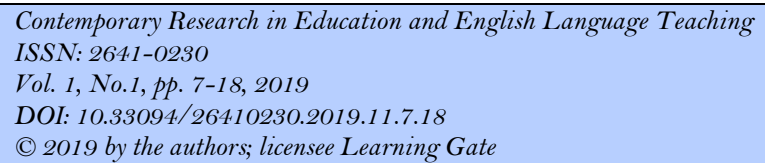


above named authorities said such technologies can be found in a host of devices, software applications, computers and connectivity, as in accessing the internet, local networking, teleconferencing among others. Unwin, (2004), postulated that, new learning technologies are information and communication technologies employed in teaching and learning to enhance the professional development and advancement of teachers and students. New technologies are those contemporary instructional materials that are capable of processing, storing, printing, retrieve, communicate, connect, transmit, transform, access, disseminate information in an accurate and faster manner to both the teachers, students and the larger society

Today, the positive role and position influence of ICT in education domain including Business Education content delivery has brought innovation and creativity in teaching and learning techniques in nursery, primary, secondary and tertiary institutions. Inije (2012) submitted that, information and communication technologies (devices) are dives set of technological devices and resources used for communication to create, disseminate, store and management information. These technological resources that are available for teaching and learning of Business Education content include; e-mail, cell-phone, internet, intranet, extranet, computer, radio, YouTube, interactive $\mathrm{CDs}$, satellite $\mathrm{TV}$, video phone system, PowerPoint, video conferencing and teleconferencing. Igberaharha (2014) added that, technologies that succeed in schools tend to define learners' goals, develop structures to guide students and provide sophisticated measures of learning outcome.

Technologies for learning maximize the active participation of the learner. In fact, such technologies are developed so that they can work for any learner, regardless of the motivation or ability of the particular learner. Technologies for learning are essentially teaching technologies structured to be a reliable device and measure learning outcomes regardless of the context or situation of the learner. Technologies for learner put the learner in control of the instructional process to allow for student-centred. Jegbefume, Utebor and Kifordu (2014) added that, new technologies components have played vital role in educational process, especially as it is related to teaching and learning Business Education content. The application of programmed instructions such as (Mavis Beacon Teaches Typing) in the teaching of Business Education content (secretarial education in computer instruction is a remarkable reference of new technologies and computer relevance to Business Education process.

Other new technologies areas are; (1) Course management system, (2) instant message (IM), (3) Podcast, (4) blogs, (5) E-portfolio (6) Zotero (collect and manage research), (7) Collaborative Authorizing, (8) Social Network tools and (9) Book-marking tools etc. In the opinion of kitchener \& Salinger (2003), new technologies motivate and encourage students to be independent learners. Abimadu (1998) said, lecturers who use new technologies in their teaching benefit from the following:

1. Assist less qualified lecturers' classroom management

2. Increase the time lecturers devote to learning

3. Increase teachers' efficiency and effectives

4. Enhance the speed of availability of data information.

Below are some of the areas Business Education content students can use new technologies to their benefits according to Ukata and Kalagbor (2014):

(1) Word processing, (2) Spread-sheet, (3) Data base management, (4) Calendar schedules, (5)Presentation (power point ), (6) Publishing and webpage maintenance, (7) Keyboarding (typewriting ), (8) Automated accounting, (9) interpersonal and written communication skills, (10) Employability job search techniques, (11) Speed and accuracy writing, (12) Human resources management, (13) Business management skills and (14) Office procedure including records management etc.

\subsection{Some New Technologies and Functions}

Ikelegbe (2007) categorized the different kinds of information and communication technologies into five basic types as:

\section{Sensing Technologies}

These are devices that help us to gather information from the environment and translate the information into a form that can be understood by computer. Examples are data collection devices such as scanners, computer keyboards, computer, and mouse. These are technologies that tie together and communication between the various kinds of technologies. Examples include fax (screen etc).

\section{Communication Technologies}

Contemporary Research in Education and English Language Teaching
ISSN: $2641-0230$
Vol. 1, No.1,pp. $7-18,2019$
DOI: $10.33094 / 26410230.2019 .11 .7 .18$
C) 2019 by the authors; licensee Learning Gate


Facsimile machine, cellular telephone, computer networks. A network is a group of devices that is linked together. Example is the private branch exchange (PBXB) which is Local Area Network (LAN) which covers several floors within a building or an entire building or ever a campus in case of the school environments. The Wide Area Network (WAN) which covers larger geographical areas and uses telephone line, microwaves and satellite communication network.

\section{Analysing Technologies}

The computer hardware and software come with this category. Computer takes information from sensing and communication devices and then store and process the information.

\section{Display Technologies}

These are essential output devices. They make processed data available to human for use either through loud speaker, printer and display screen like photocopying machines.

\section{Storage Technologies}

This is another important category of I.C.T. They help us to store large quantities of information in a form that can be easily accessed. This is made up of the secondary storage devices such as magnetic tape, magnetic disc, optical disc (CD-ROMs Read Only Memory, VCDs, and Video Compact Disc etc). Lemke (2004) other new technologies for instructional delivery are:

\section{Computer Assisted Instruction (CAI)}

Is the term used to describe the use of computer to provide instruction to students by simulating teaching and learning. Opportunities in the classroom are in the areas of drift and practice, tutorial, simulation demonstration designing, data collection, analysis and games.

In the case of CMI, Abimbola (1998) observed that students do not receive any instruction from the computer, rather students' instructions are managed using computer. Harold and Oneil (1999) classified the functions performed by CMI into two: Instruction management and Function support. The support for basic group of users, including students' instructions administrators and curriculum developers and evaluators. The instructional management related functions as discussed by Harold and Oneil (1999) including the following:

\section{i. Diagnosis}

This is the process by which ranges of instructional alternatives are suggested based on diagnosis to either the students or the teacher.

\section{ii. Performance Monitoring}

This involves the process by which an individual and groups rate of progress is watched and supervised closely. Both students and teachers performance are monitored and this supports planning and evaluation.

\section{iii. Resource Allocation/Scheduling}

This is the process for allocating of instructional resources specified by the prescriptive process within a particular time frame in order to make the most effective use of the available resources.

\section{iv. Reporting}

This involves a process by which one retrieves and updates information used on characteristics of the information via a data system and by which information is tabulated and formulated in a form interpretable by human beings.

\section{v. Data Base Use}

Students and teachers can use computer to keep and produce records (i.e. Information storage and retrieval) about current events and other disciplines.

\section{Computer Aided Design (CAD)}

Another dynamic use of Computer in the classroom is through computer aided design. CAD offers a variety of 3-dimentional and modelling and visualization features. CAD is also successful in instructional 
applications because teachers, designers and students have unlimited access to a wide range of vital design materials and construction techniques that make it possible to explore more advance technical designs.

\section{Programming}

Computer Programming is the art of conceiving a problem in term of the steps to its solution and expressing those steps as instruction for the computer to follow. Bright man programming language is a collection of commands that directs the control of a computer programmes and run the same on the computer. Students and teacher can develop their programmes using special computer languages like BASIC (Beginner's All-Purpose Symbolic Instruction Code) PASCAL RGP (Report Program Generator), FORTRAN and COBOL. Students will finds it interesting in converting their ideas into executed programmes.

\section{Problem Solving}

Computer is invading the educational system in a way unparalleled in previous education history.

Computer permits students to develop programmes and to suit the programmes to solve numerous problems. Information and Communication Technology are generally accepted as a modern instrumental tool that enables the educators to modify their teaching methods they use in order to increase students' interest and to facilitate learning. Some of the used for learning include:

\section{i. E-Learning}

This is the main Information and Communication Technology new education tool for teaching and learning. E-Learning usually refers to structured and managed learning experience and may be provided partially or wholly via a web browser or through the internet or an intranet or multimedia platform such as CD-Rom or DVDs, or other media and communications.

\section{ii. Video Lecture}

These are specially prepared lectures that are transmitted live on the internet or can be access from a website at any time. Charts and diagrams etc. can be accessed separately.

\section{iii. E-Library}

There are thousands of books that a person can find access via the internet. This is very good for research and it's used to increase knowledge.

\section{iv. Internet}

This is a global collection of many types of computer and computer networks that are linked together.

\subsection{Challenges of New Technologies in Teaching and Learning Business Education \\ 1.3.1. Inadequate Funding}

According to Acharu and Solomon (2014); Amesi, Dorathy and Giami noted inadequate infrastructural (instructional) resources are evidently linked to inadequate funding by Governments. This situation is so bad that funding is usually in response to conditionality's imposed by International Financial Institutions (IFIS). Despite the foregoing, Nigeria still remains a major defaulter in complying with the UNESCO recommendations that at least 26 per-cent of the National Budget must be committed to education.

\subsection{Poor Policy Implementation}

There is lack of well -articulated educational policy by the Nigerian government. More attention is given to other sectors than to education. This posing problem to the provision of instructional resources especially for the acquisition of entrepreneurial skills.

\subsection{Lack of Maintenance Culture}

According to Udin and Uwaifor (2007), most equipment and infrastructure in Nigeria are in despair and decay due to poor maintenance culture. Absence of maintenance culture in our school systems has caused a major setback to effective implementation of entrepreneurship programme and new technologies. Equipment that breaks down in public institutions is sometimes difficult to repair. In such case damaged equipment continue to depreciate till it finally become dead. Miller and Akume (2009) noted that all stakeholders in the 
educational sectors are expected to be partners in the maintenance of school equipment while parents and government are to provide finance for maintenance activities. In the same way, school authorities are to detect fault and utilize fully the available equipment

\subsection{Corruption in Education System}

The Nigeria education system has witnessed unprecedented anomalies in terms of fund diversion, bribery and falsification of unverifiable projects to the personal gains of individuals and to the detriment of education in Nigeria. Corruption has crippled the provision of educational materials to a sorry level that some government owned institutions do not have the necessary materials for effective teaching and learning. Laboratories and classroom are empty, no befitting office accommodation and furniture for lecturers. Priye (2016) lamented that corruption began to have its serious and negative effects on education in the middle and late $1980^{\circ \mathrm{s}} \mathrm{s}$ as the psychosocial beast beclouded the minds of those who ruled Nigeria. According to Priye, the scramble to loot as much as possible by those in position of power resulted in the neglect of the educational sector and affected the availability of the desire new technologies negatively.

\subsection{Students' Attitudes toward Educational Facilities}

The belief that government property is nobody's property sometimes affects the availability, maintenance and continuity of instructional equipment in our tertiary institutions. The syndrome of "it is government property" has become a canker worm eating deep into the very fabric of our educational system as students mishandle equipment and go free. This does result to inadequacy of new instructional materials and the blame to educational authorities. Puyate in Acharu \& Solomon (2012) supported this when he opined that "there is little or no concern on the part of government, lecturers and students for the improvement of the present state of facilities in tertiary institutions. Students must be sensitized on how to take good care of educational facilities for the benefit of effective teaching and learning.

\subsection{Increase in Students' Enrolment}

Business Education of which entrepreneurship is an integral part has been experiencing incremental movement in the number of students"e enrolment as a result of the quest for a discipline that can make one selfreliant and productive after graduation. As a result, the number of information and communication technology instructional based equipment such as computers, laboratories and classrooms are always insufficient for effective teaching and learning of Business Education programme.

\subsection{Unqualified Teachers}

Teachers are critical stakeholders in curriculum implementation. The employment of unqualified teachers to teach business courses is a great disservice to quality of Business Education graduates. It is a well-known fact that most of the higher institutions that offer Business Education programme suffer from shortage of qualified teachers. Business Education has become a dumping ground for all sorts of graduates from different disciplines employed in the name of business educator.

\subsection{Poor Students` Background before Admission}

Most students have little or no knowledge of the use of new technologies before admission. There are also problem of high cost of ICT equipment, ICT illiteracy among teachers, poor power supply and poor internet connectivity

\subsection{Statement of the Problem}

Over the centuries even with evolution of classroom new technologies and management, teachers and students have depended on orthodox instructional technologies and techniques such as Beads, Wooden Roller, Counting sticks, striking on the wall with Charcoal and Cane for demonstration etc., and instructional techniques like "talk and write" "listen and take note" "dictate and explain. Today, teaching and learning have been revolutionized because of the introduction of new technologies in the global market. Business Education as a course content that is rooted with entrepreneurial skills cannot be adequately delivered without the use of new technologies. It is on this premise that this study is been carried out to find out the challenges of teaching and learning Business Education with new technologies in Rivers State universities. 


\subsection{Purpose of the Study}

The purpose of this study is to find out challenges of teaching and learning Business Education with new technologies in Rivers State universities. The study specifically seeks to:

1. Find out the level of significant difference between RSU students opinions and IAUE students on the level of availability of new technologies in teaching and learning Business Education in Rivers State Universities

2. Determine the level of significant difference between RSU students' opinions and IAUE students on the level of types of challenges of new technologies in the teaching and learning of Business Education in Rivers State Universities

\subsection{Research Questions}

The under stated research questions were posed to guide this study

1. What is the level of significant difference between RSU students' opinions and IAUE students on the level of availability of new technologies in teaching and learning Business Education in Rivers State Universities?

2. What is the level of significant difference between RSU students' opinions and IAUE students on the level of the types of challenges of new technologies in teaching and learning of Business Education in Rivers State Universities?

\subsection{Hypotheses}

Two null hypotheses were formulated and tested at 0.05 level of significance

1. There is no significant difference between the opinions of RSU students' and IAUE students on the level of availability of new technologies and teaching and learning of Business Education in Rivers State Universities

2. There is no significant difference between the opinions of RSU students' and IAUE students on the level of types of challenges of new technologies and teaching and learning of Business Education in Rivers State Universities

\section{Method}

The study adopted a survey research design, because it involved finding out if there is difference between the opinions of the two schools concerning the variables under investigation. The study covered Rivers State University (RSU) and Ignatius Ajuru University of Education (IAUE). The population of the study was numbered 2, 989 of years 1 to years 4. The breakdown is as stated below using Exploded Pie Chart in 3-D for the presentation of the population

\section{A BREAKDOWN OF THE POPULATION OF THE STUDY OF 2,989/PERCENTAGES}

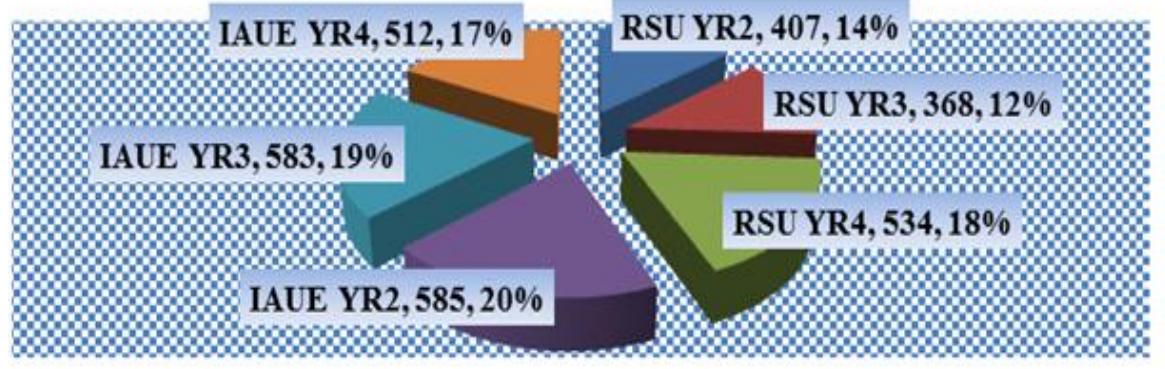

\section{- RSU YR2 \\ - RSU YR3 \\ RSU YR4 \\ -IAUE YR2 \\ IAUE YR3 \\ IAUE YR4}

Figure-1. Exploded Pie Chart in 3-D. Presentation of the Population

Sample size was 341 using Krejcie and Morgan sampling technique. The Sample Size is as presented in Exploded Pie Chart in 3-D below: 


\section{NAME OF THE UNIVERSITY, YEAR AND SAMPLE SIZES OF THE STUDY TOTALLING 341,} INCLUDING THE PERCENTAGES OF EACH

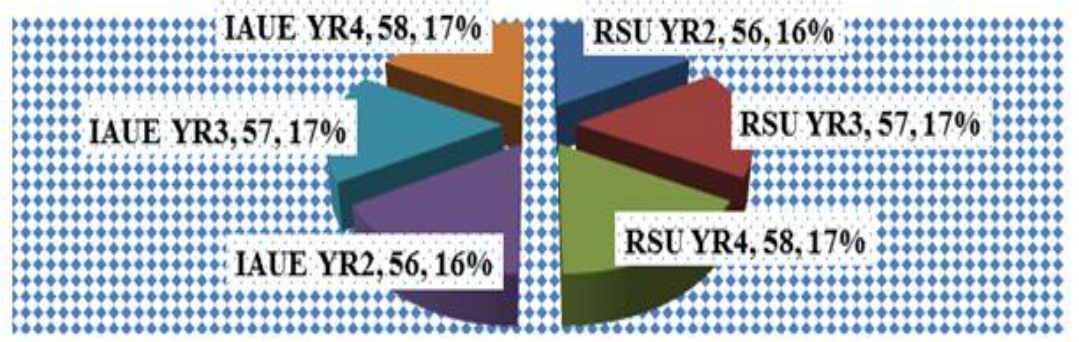

- RSU YR2

-RSU YR3

aSU YR4

-IAUE YR2

IAUE YR3

IAUE YR4

Figure-2. Exploded Pie Chart in 3-D. Presentation of the Sample Size

The instrument used was tagged "Challenges of Teaching and Learning Business Education with New Technologies (COTALBEWINT)", with a five point scale of Very High Extent of Challenges (5 Points), High Extent of Challenges (4 Points), Moderate Extent of Challenges (3 Points), Low Extent of Challenges (2 Points), and Very Low Extent of Challenges (1 Point). The instrument was validated by three experts and a two week field trial of test retest was done to know the internal consistency. 341 copies of questionnaire items were face-to-face administered to the respondents and 330 successfully retrieved. Arithmetic mean was used to analyse the research questions, and Standard Deviation used to find out the extent in which scores in the distribution clustered around the means. T-test was adopted as statistical tool to test the hypotheses to determine the extent of the significant difference between the opinions of the two groups of respondents on challenges of teaching and learning Business Education with new technologies in Rivers State universities. Mean scores of 5.0, 4.0, and 3.0 were seen as Very High Extent of Challenges(VHEC 5Points), High Extent of Challenges (HEC 4Points), Moderate Extent of Challenges (MEC 3Points), while 2.0 and 1.0 were seen as Low Extent of Challenges (LEC 2 Points) and Very Low Extent of Challenges (VLEC 1Point). The decision point is that any calculated ground mean from 3.0 and above will be rejected and any ground mean below 3.0 will be accepted. Also, any calculated value of T-test that is greater than $>$ the critical table value of 1.96 at 0.05 significant levels such null hypothesis $\left(\mathrm{H}_{\mathrm{O}}\right)$ will be rejected, but if the critical table value is greater than $>$ the computed value such null hypothesis will be accepted.

Research Question 1: What is the level of significant relationship between RSU students' opinions and IAUE students on the level of availability of new technologies in teaching and learning Business Education in Rivers State Universities?

Table 1.

The Level of Availability New Technologies in Teaching and Learning Business Education

\begin{tabular}{|c|c|c|c|c|c|c|c|c|c|c|}
\hline \multicolumn{11}{|c|}{$\begin{array}{l}\mathrm{N}=165 \\
\mathrm{TNR}=\text { Total Number of Responses }\end{array}$} \\
\hline SN & Items Statements & $\begin{array}{l}\text { VHEC } \\
(5)\end{array}$ & $\begin{array}{l}\text { HEC } \\
(4)\end{array}$ & $\begin{array}{l}\text { MEC } \\
(3)\end{array}$ & $\begin{array}{l}\text { LEC } \\
(2)\end{array}$ & $\begin{array}{l}\text { VLEC } \\
\text { (1) }\end{array}$ & $\begin{array}{ll}\mathbf{T} & \mathbf{N} \\
\mathbf{R} & \end{array}$ & $\mathbf{X}$ & SD & Remark \\
\hline 1 & $\begin{array}{l}\text { Functional } \\
\text { availability in teaching and } \\
\text { learning Business Education } \\
\text { programme }\end{array}$ & $\begin{array}{l}30 \\
(150)\end{array}$ & $\begin{array}{l}30 \\
(120)\end{array}$ & $\begin{array}{l}10 \\
(30)\end{array}$ & $\begin{array}{l}70 \\
(140)\end{array}$ & $\begin{array}{l}35 \\
(35)\end{array}$ & 475 & 2.8 & 1.6 & LEC \\
\hline 2 & $\begin{array}{l}\text { Functional Laptops in } \\
\text { teaching and learning } \\
\text { Business Education }\end{array}$ & $\begin{array}{l}20 \\
(100)\end{array}$ & $\begin{array}{l}20 \\
(60)\end{array}$ & $\begin{array}{l}50 \\
(150)\end{array}$ & $\begin{array}{l}10 \\
(20)\end{array}$ & $\begin{array}{ll}65 \\
(65)\end{array}$ & 415 & 2.5 & 1.5 & LEC \\
\hline 3 & $\begin{array}{l}\text { Functional Palmtop } \\
\text { availability in teaching and } \\
\text { learning Business Education }\end{array}$ & $\begin{array}{l}155 \\
(775)\end{array}$ & $\begin{array}{l}10 \\
(40)\end{array}$ & $\begin{array}{l}0 \\
(0)\end{array}$ & $\begin{array}{l}0 \\
(0)\end{array}$ & $\begin{array}{l}0 \\
(0)\end{array}$ & 815 & 4.9 & 2.2 & HES \\
\hline 4 & $\begin{array}{l}\text { Functional Notebook } \\
\text { available in teaching and } \\
\text { learning Business Education }\end{array}$ & $\begin{array}{l}165 \\
(500)\end{array}$ & $\begin{array}{l}0 \\
(0)\end{array}$ & $\begin{array}{l}0 \\
(0)\end{array}$ & $\begin{array}{l}10 \\
(20)\end{array}$ & $\begin{array}{l}0 \\
(0)\end{array}$ & 700 & 4.2 & 2.0 & HEC \\
\hline 5 & $\begin{array}{l}\text { Functional Personal } \\
\text { Computer in teaching and } \\
\text { learning Business Education }\end{array}$ & $\begin{array}{l}120 \\
(825)\end{array}$ & $\begin{array}{l}45 \\
(180)\end{array}$ & $\begin{array}{l}0 \\
(0)\end{array}$ & $\begin{array}{l}0 \\
(0)\end{array}$ & $\begin{array}{l}0 \\
(0)\end{array}$ & 825 & 5 & 2.2 & HEC \\
\hline
\end{tabular}




\begin{tabular}{|c|c|c|c|c|c|c|c|c|c|c|}
\hline 6 & $\begin{array}{l}\text { Availability of Functional } \\
\text { Digital Light Projector (DLP) } \\
\text { in teaching and learning } \\
\text { Business Education }\end{array}$ & $\begin{array}{l}30 \\
(150)\end{array}$ & $\begin{array}{l}30 \\
(60)\end{array}$ & $\begin{array}{l}10 \\
(30)\end{array}$ & $\begin{array}{l}70 \\
(140)\end{array}$ & $\begin{array}{l}35 \\
(35)\end{array}$ & 475 & 2.8 & 1.4 & LEC \\
\hline 7 & $\begin{array}{l}\text { Availability of internet } \\
\text { connectivity in teaching and } \\
\text { learning Business Education } \\
\text { Availability of network } \\
\text { Studios }\end{array}$ & $\begin{array}{l}155 \\
(775)\end{array}$ & $\begin{array}{l}10 \\
(40)\end{array}$ & $\begin{array}{l}0 \\
(0)\end{array}$ & $\begin{array}{l}0 \\
(0)\end{array}$ & $\begin{array}{l}0 \\
(0)\end{array}$ & 815 & 4.9 & 2.1 & HEC \\
\hline 8. & & $\begin{array}{l}120 \\
(825) \\
\end{array}$ & $\begin{array}{l}10 \\
(40) \\
\end{array}$ & $\begin{array}{l}0 \\
(0) \\
\end{array}$ & $\begin{array}{l}0 \\
(0) \\
\end{array}$ & $\begin{array}{l}0 \\
(0) \\
\end{array}$ & 815 & 4.9 & 2.1 & \\
\hline & Grand mean & & & & & & & 4 & & HEC \\
\hline
\end{tabular}

Source: Field Survey, (2018)

In analysing research question one and statement items on table 1, the means and standards deviations from items numbered 1 to 8 are as stated below: 1. Availability of functional desktop for teaching and learning Business Education, $\mathrm{X}=2.8$ and $\mathrm{SD}=1.6$, meaning low extent challenges and closeness in the view of the respondents, this is accepted according the cut-off point. 2. Availability of functional laptops, $\mathrm{X}=2.5$ and $\mathrm{SD}=1.5$, meaning low extent of challenges and nearness in the opinion of the students, this is accepted. 3. Availability of functional palmtop, $\mathrm{X}=4.9$ and $\mathrm{SD}=2.2$, meaning high extent of challenges and closeness in views of the respondents, this is not accepted. 4 . Availability of notebook, $\mathrm{X}=4.7$ and $\mathrm{SD}=2.1$ meaning high extent of challenges and nearness in the views of the students, this is not accepted.

5. Availability of function personal computer, $\mathrm{X}=5$ and $\mathrm{SD}=2.2$, representing very high extent of challenges and nearness in the views of the respondents, this is not accepted. 6. Availability of digital projector, $\mathrm{X}=2.1$ and $\mathrm{SD}=1.2$, representing low extent of challenges and closeness in the views of the respondents, this is accepted. 7. Availability of internet connectivity, $\mathrm{X}=4.9$ and $\mathrm{SD}=2.2$, representing high extent of challenges and closeness in the views of the respondents, this is not accepted. 8. Availability of network studios, $\mathrm{X}=4$ and $\mathrm{SD}=2.19$, representing high extent of challenges and closeness in the views of the respondent. The grand mean is 4; this means there is a high extent of challenges in the availability of new technologies in teaching and learning Business Education and not accepted.

Research Question 2: What is the level of significant relationship between RSU students' opinions and IAUE students on the level of the types of challenges of new technologies in teaching and learning of Business Education in Rivers State Universities?

Table 2.

The Level of Types of Challenges of New Technologies in Teaching and Learning Business Education

\begin{tabular}{|c|c|c|c|c|c|c|c|c|c|c|}
\hline \multicolumn{11}{|c|}{$\begin{array}{l}\mathbf{N}=165 \\
\text { TNR = Total Number of Responses }\end{array}$} \\
\hline $\mathbf{S ~ N}$ & Items Statements & $\begin{array}{l}\text { VHEC } \\
(5)\end{array}$ & $\begin{array}{l}\text { HEC } \\
(4)\end{array}$ & $\begin{array}{l}\text { MEC } \\
(3)\end{array}$ & $\begin{array}{l}\text { LEC } \\
(2)\end{array}$ & $\begin{array}{l}\text { VLEC } \\
(1)\end{array}$ & $\begin{array}{ll}\mathbf{T} & \mathbf{N} \\
\mathbf{R} & \\
\end{array}$ & $\bar{X}$ & SD & Remark \\
\hline 1 & $\begin{array}{l}\text { Unqualified Teachers } \\
\text { in Business Education } \\
\text { programme }\end{array}$ & $\begin{array}{l}20 \\
(100)\end{array}$ & $\begin{array}{l}10 \\
(40)\end{array}$ & $\begin{array}{l}20 \\
(60)\end{array}$ & $\begin{array}{l}20 \\
(40)\end{array}$ & $\begin{array}{l}90 \\
(10)\end{array}$ & 250 & 1.5 & 1.2 & VLEC \\
\hline 2 & $\begin{array}{l}\text { Increase in students' } \\
\text { enrolment } \\
\text { in Business Education }\end{array}$ & $\begin{array}{l}110 \\
(550)\end{array}$ & $\begin{array}{l}55 \\
(220)\end{array}$ & $\begin{array}{l}\mathrm{O} \\
(\mathrm{O})\end{array}$ & $\begin{array}{l}\mathrm{O} \\
(0)\end{array}$ & $\begin{array}{l}\mathrm{O} \\
(0)\end{array}$ & 770 & 4.6 & 2.0 & $\mathrm{HEC}$ \\
\hline 3 & $\begin{array}{lr}\text { Poor } & \text { Students } \\
\text { Background } & \text { Before } \\
\text { Admission } & \\
\text { in Business Education }\end{array}$ & $\begin{array}{l}95 \\
(475)\end{array}$ & $\begin{array}{l}45 \\
(180)\end{array}$ & $\begin{array}{l}20 \\
(60)\end{array}$ & $\begin{array}{l}0 \\
(0)\end{array}$ & $\begin{array}{l}\mathrm{O} \\
(\mathrm{O})\end{array}$ & 715 & 4.3 & 2.0 & HEC \\
\hline 4 & $\begin{array}{l}\text { Students' attitudes toward } \\
\text { educational facilities } \\
\text { in Business Education }\end{array}$ & $\begin{array}{l}90 \\
(450)\end{array}$ & $\begin{array}{l}50 \\
(200)\end{array}$ & $\begin{array}{l}20 \\
(60)\end{array}$ & $\begin{array}{l}5 \\
(10)\end{array}$ & $\begin{array}{l}\mathrm{O} \\
(\mathrm{O})\end{array}$ & 720 & 4.3 & 2.0 & HEC \\
\hline 5 & $\begin{array}{l}\text { Corruption in education } \\
\text { system in } \\
\text { Education }\end{array}$ & $\begin{array}{l}100 \\
(500)\end{array}$ & $\begin{array}{l}60 \\
(240)\end{array}$ & $\begin{array}{l}5 \\
(15)\end{array}$ & $\begin{array}{l}\mathrm{O} \\
(\mathrm{O})\end{array}$ & $\begin{array}{l}\mathrm{O} \\
(\mathrm{O})\end{array}$ & 755 & 4.5 & 2.1 & HEC \\
\hline
\end{tabular}




\begin{tabular}{|l|l|l|l|l|l|l|l|l|l|l|}
\hline $\mathbf{6}$ & $\begin{array}{l}\text { Lack of maintenance } \\
\text { In Business Education }\end{array}$ & $\begin{array}{l}90 \\
(450)\end{array}$ & $\begin{array}{l}50 \\
(200)\end{array}$ & $\begin{array}{l}20 \\
(60)\end{array}$ & $\begin{array}{l}5 \\
(10)\end{array}$ & $\begin{array}{l}0 \\
(0)\end{array}$ & 720 & 4.3 & 2.0 & HES \\
\hline $\mathbf{7}$ & $\begin{array}{l}\text { Poor policy } \\
\text { implementation of Business } \\
\text { Education }\end{array}$ & $\begin{array}{l}100 \\
(500)\end{array}$ & $\begin{array}{l}30 \\
(120)\end{array}$ & $\begin{array}{l}20 \\
(60)\end{array}$ & $\begin{array}{l}10 \\
(20)\end{array}$ & $\begin{array}{l}0 \\
(0)\end{array}$ & 700 & 4.2 & 2.0 & HEC \\
\hline $\mathbf{8}$ & $\begin{array}{l}\text { Inadequate funding of } \\
\text { Business Education }\end{array}$ & $\begin{array}{l}100 \\
(500)\end{array}$ & $\begin{array}{l}60 \\
(240)\end{array}$ & $\begin{array}{l}5 \\
(15)\end{array}$ & $\begin{array}{l}0 \\
(0)\end{array}$ & $\begin{array}{l}0 \\
(0)\end{array}$ & 755 & 4.5 & 2.1 & HEC \\
\hline & Grand Mean & & & & & & $\mathbf{4 . 0}$ & & \\
\hline
\end{tabular}

Source: Field Survey, (2018)

In analysing research question two and statement items, number 1 with unqualified teachers has $\mathrm{X}=1.5$ and $\mathrm{SD}=1.2$ representing very low extent of challenges and closeness in the views of the respondents.

2. Increase in students 'enrolment, $\mathrm{X}=4.6$ and $\mathrm{SD}=2.0$ representing high extent of challenges and closeness in opinions of the respondents .3. Poor student new technologies background before admission, $\mathrm{X}=$ 4.3 and $\mathrm{SD}=2.0$, representing high extent of challenges and closeness in the views of the respondents 4 . Students attitudes towards educational facilities, $\mathrm{X}=4.3$ and $\mathrm{SD}=2.0$ representing high extent of challenges and closeness in the opinions of the respondents. 5. Corruption in education, $\mathrm{X}=4.5$ and $\mathrm{SD}=2.1$ representing high extent of challenges and closeness in the opinions of the respondents. 6 . Lack of maintenance, $\mathrm{X}=4.3$ and $\mathrm{SD}=2.0$, representing high extent of challenges and nearness in the views of the respondents. 7. Poor policy implementation, $\mathrm{X}=4.2$ and $\mathrm{SD}=2.0$ representing high extent of challenges and closeness in views of the students. 8. Inadequate funding, $\mathrm{X}=4.5$ and $\mathrm{SD}=2.1$, representing high extent of challenges. Since the grand mean is 4.0 it means there is high extent of challenges in the level of types of challenges of new technologies in teaching and learning Business Education in Rivers State Universities

Hypothesis 1: There is no significant difference between the opinions of RSU students' and IAUE students on the level of availability of new technologies and teaching and learning of Business Education in Rivers State Universities

Table 3.

Summary Table of Calculated T-test on the opinions of RSU and IAUE on the Level of Availability of New Technologies in Teaching and Learning Business Education

\begin{tabular}{|l|l|l|l|l|l|l|l|l|l|}
\hline SN & SCHOOL & MEAN & SD & N & DF & SE & T-CAL. & T-TAB & DECISION \\
\hline $\mathbf{1}$ & RSU & $\mathbf{1 . 2}$ & $\mathbf{1 . 0}$ & 165 & & 0.09 & & & \\
\hline & & & & & $\mathbf{1 6 3}$ & & $\mathbf{0 . 9 8}$ & $\mathbf{1 . 9 6}$ & ACCEPTED \\
\hline $\mathbf{2}$ & IAUE & $\mathbf{1 . 3}$ & $\mathbf{1 . 1}$ & 165 & & 0.10 & & & \\
\hline
\end{tabular}

Source: Field Survey, (2018)

The calculated t-test 0.98 is less than $(<)$ the critical table value of 1.96 at 0.05 significant levels. Since the calculated value of t-test 0.98 is less than $(<)$ the critical table value of 1.96, the null hypothesis which stated that there is no significant difference between the opinions of RSU students' and IAUE students on the level of availability of new technologies and teaching and learning of Business Education in Rivers State Universities is upheld

Hypothesis 2: There is no significant relationship between the opinions of RSU students' and IAUE students on the level of types of challenges of new technologies and teaching and learning of Business Education in Rivers State Universities

Table 4.

Summary Table of Calculated T-test on the opinions of RSU and IAUE on the Level of Challenges of New Technologies in Teaching and Learning of Business Education

\begin{tabular}{|l|l|l|l|l|l|l|l|l|l|}
\hline SN & SCHOOL & MEAN & SD & N & DF & SE & T-CAL. & T-TAB & DECISION \\
\hline $\mathbf{1}$ & .RSU & 1.0 & 1.0 & 165 & & 0.07 & & & \\
\hline & & & & & $\mathbf{1 6 3}$ & & $\mathbf{0 . 9 9}$ & $\mathbf{1 . 9 6}$ & ACCEPTED \\
\hline $\mathbf{2}$ & IAUE & 1.3 & 1.1 & 165 & & 0.10 & & & \\
\hline
\end{tabular}

Source: Field Survey, (2018)

The calculated t-test 0.99 is less than $(<)$ the critical table value of 1.96 at 0.05 significant levels. Since the calculated value of t-test 0.99 is less than $(<)$ the critical table value of 1.96, the null hypothesis which stated 
that there is no significant difference between the opinions of RSU students' and IAUE students on the level of types of challenges of new technologies and teaching and learning of Business Education in Rivers State Universities is accepted.

\section{Discussion of Findings}

From the analysis of research question one, the grand mean showed 4; is representing high extent of challenges in the availability of new technologies in teaching and learning Business Education. This finding is in agreement with the view of Amesi and Giami (2007), who opined that resources and other infrastructure in tertiary institutions offering entrepreneurship education programme are dilapidated, inadequate, over used and a death trap in some cases.

Inadequate and unavailability of new technological resources has made teaching and learning process not to function effectively because students do not acquire the necessary entrepreneurial skills they need to be selfreliant. According to Udin and Uwaifor (2007), most equipment (new technologies) and infrastructure in Nigeria are in despair and decay due to poor maintenance culture. In analysing research question two, the grand mean indicated 4.0. This means that there is high extent of challenges in the level of types of challenges of new technologies in teaching and learning Business Education in Rivers State Universities. This could be the reason Priye (2016) lamented that corruption began to have its serious and negative effects on education in the middle and late $1980^{\mathrm{ee}} \mathrm{s}$ as the psychosocial beast beclouded the minds of those who ruled Nigeria. Miller and Akume (2009) also noted that all stakeholders in the educational sectors are expected to be partners in the maintenance of school equipment while parents and government are to provide finance for maintenance activities. In addition, Fafunwa (2010) observed that a large number of students are crowded in classrooms, using inadequate and obsolete equipment and with disillusioned teachers.

\section{Conclusion}

From the finding of the study, it is concluded that there was high extent of challenges in the availability of new technologies and high extent of challenges in the level of types of challenges of new technologies and teaching and learning of Business Education

\section{Recommendations}

1. Government and other concerned agencies should ensures new technologies are made available in there right quantities and qualities for the teaching and learning of Business Education

2. There should be adequate funding, regular training and retraining of teachers

3. There should be proper policy formulation and implementation about Business Education on students' enrolment, programme content, process and output

\section{References}

Abimbola, I. O. (1988). The role of computer in education. National Journal of Technical Education, 5: 26-33.

Abimadu, A. (1998). Information technology. The current strategy effective science and technology instruction. Bichi journal of Education, 21: 33-39.

Acharu, S. T. \& Solomon, E. (2014). Influence of infrastructure on the teaching and learning of office education in polytechnics - ABEN Conference Proceedings, (1): 78-82

Amesi, J. \& Giami, D.K (2018). Challenges hindering the availability of instructional resources for entrepreneurial skills acquisition among business education students in tertiary institutions, Rivers State. International Journal of Education and Evaluation, 4(1).

Amoor, S.S. (2010). The need to improve teacher quality in business education in Nigerian universities. International Journal of Education Research, 11(1): 1-11.

Awotua-Efebo, E. B. (1999). Effective teaching, principles and practice. Port Harcourt: Imprint of Jeson Services.

Ekundayo, H.T. (2009). Prospect of information and communication technology in academic activities in Nigeria tertiary institutions. Journal of Research and Industrial Development, 7(1): 122-126.

Fafunwa, A.B. (2010). Fafunwaes Last Interview: Remember me as Somebody who Promoted use of Mother Tongue in Schools. The Punch (P3), October, 13, 2016.

Haagi, S., Cummings, M. \& McCubbery, D. T. (2002). Management information system for information age. (3rdEdn.,). Boston: McGraw.

Harold, F. \& Oneil, J. (1999). Computer based instruction: A state of art assessment. London: Sage Publication

Igberaharha, O.C. (2014), Challenges of new technologies and mentoring in teaching and learning business education in Delta State tertiary institutions. Nigeria Journal of Business Education, 2(1): 92-104. 
Ikelegbe, S. (2007). Information and Communication Technology: As a tool for Developing Nigerian Education Sector. Journal of Business Studies and Technology Development, 1(2): 73-77.

Inije, G.O.,Utoware, J.D.A., \& Kren-Ikidi, P.C. (2013).Utilization of e-learning technologies in business education instructional delivery in Colleges of Education in Delta State of Nigeria. International Journal of Education and Research, 1(10).

Jegbefume, F.M.,Utebor, J \& Kifordu, A.A. (2014). Challenges in the use of new learning technologies in business education programme. Nigeria Journal of Business Education, 2(1): 306-312

Miller, O. \& Akume, B. C. (2009, September 10th). The State of equipment provision and maintenance for the teaching of Business Studies at the Junior Secondary School. Retrieved from www.gamji.comarticle6000/news7987.htm

Onyesom, M. (2014). Pedagogical elements of the new technologies for teaching and learning business education. Nigeria Journal of Business Education, 2 (91): 125-131.

Onyesom, M \& Utoware, J. D. A. (2012). Perceived benefit and challenges in ICT in business education. Nigerian Journal of Business Education, 1 (1): 82-90

Osuala, E.C. (2004). Principles and methods of business and computer education. Enugu: Cheston

Priye, S. T. (2016, July 11 th). The corrosive effect of corruption on Nigeria educational

Solomon, G. (2012, May 20th). An examination of entrepreneurship education in United States. Journal of small business and enterprise development, 14(2), 168 -182. Retrieved from http://dx.doi.org/10.1108/1462600071074663706/09/2015

Theelearningcoach.com, (2018, August, 19th). 10 Definitions of learning. http://theelearningcoach.com/learning/10definitions-learning/

Udin, P. S. O. \& Uwaifor, V. O. (2007). Principles and practice of vocational and technical education in Nigeria. Benin City: Ever Blessed Publishers.

Ugwuogo, C.C. (2013).Business education and national development: issues and challenges. Journal of Educational and Social Research, 3(4).

Ukata, P.F. (2017). Assessment of regular development/implementation of OTM curriculum. Lambert Academic Publishing. Mauritius: Beau Bassin

Ukata, P.F. \& Kalagbor, P. I. (2015).Benchmarking: a veritable tool for efficiency and effectiveness in office education. African Social and Educational Journal, Nigeria Edition, 4 (1): 153-164.

Uwin, T. (2004, September 31st).Towards a frame work for the use of ICT in teacher training in Africa. Retrieved from. http: iiwww. open learning gg.rhul.ac.uk/ict4d/ict\% (20)11 